\title{
Developing Learner Autonomy: The Perceptions and Needs of Japanese EFL Learners
}

\author{
Koki Tomita \\ Soka University, Tokyo, Japan \\ Maho Sano \\ Soka University, Tokyo, Japan
}

\begin{abstract}
Learner autonomy is one of the keys to successful language learning. Although Asian learners have been described as rather less autonomous compared with their Western counterparts, any learner can be autonomous if adequate support is provided. This study investigated the perceptions of Japanese university EFL learners in developing learner autonomy and explored how teachers can guide their learners to be more autonomous. An online questionnaire and semistructured interviews were conducted with both lower and higher proficiency learners. The study results show that learners of different proficiency levels have varying needs to enhance their learner autonomy. However, regardless of their current proficiency and autonomy levels, the participants expressed the need for teacher support to increase their autonomy levels. Based on their needs, this study offers possible autonomy enhancing classroom practices that are level appropriate.
\end{abstract}

Since its contribution to successful language has been widely accepted, for some decades now enhancing learner autonomy (LA) has been a major theme in language education. However, what is frequently said is that LA is rather a Western concept, and not suitable for Asian contexts (Sakai, Takagi, \& Chu, 2010). Nevertheless, Asian students can demonstrate levels of LA as high as those of their Western counterparts if adequate LA training is provided (Ahmadi \& Mahdavi-Zafarghandi, 2013; Littlewood, 1999). Nunan (2003) supports this view, stating that autonomy and dependence exist on a continuum and are not completely distinct constructs; degrees and levels of autonomy exist. Bearing this idea in mind, regardless of the cultural contexts in which learners learn, teachers can play a significant role in guiding learners to be more autonomous (Chan, Spratt, \& Humphreys, 2002).

Although a large body of literature exists regarding LA, research that focuses on LA and proficiency levels in a Japanese university EFL context is still scarce. Based on the premise that Asian learners can be autonomous, this study focuses on examining the LA perceptions of Japanese university EFL learners and aims at exploring ways through which teachers can encourage learners to attain higher levels of LA. In this paper, the perceptions of lower and higher proficiency learners in developing autonomy will be explored, and then practical ideas for promoting LA will be outlined so that teachers can encourage both lower and higher

Language Education in Asia, 2016, オ2), 114-130. https://doi.org/10.5746/LEiA/16/V7/I2/A05/Tomita_Sano 
proficiency learners to develop their LA. After presenting related literature, the methodology used in this study will be described. Following the presentation of the major findings of the current study, the analysis of the results and educational implications will be outlined.

\section{Literature Review}

In the last four decades, the concept of LA has been applied in a number of contexts in language learning and has been evolving in many directions to adapt to regional differences and levels of students. In defining LA, the notion overall is often conceptualized from two different angles. The first angle looks at students' involvement in classroom management, which was initially pointed out by Nunan (2003). For Nunan, students should be involved in the decision making process to create a more autonomy-enhancing environment in which students can take more initiative in their language learning based on their preferences.

The second view is that teachers / instructors should promote self-guided learning by giving students opportunities to choose their materials on their own. As part of the development of learner autonomy, Holec (1981) suggested fostering the ability to select methods and techniques to be used for language learning. Aligning with the classic definition of learner autonomy, "to have and to hold the responsibility for all the decisions concerning all aspects of this learning" (Holec, 1981, p. 3), the ability of learners to select materials or learning activities based on their needs is a necessary precursor of LA that teachers should not forget to include in their curricula (Nunan, 2003).

Self-reflection is a skill that enables learners to proactively engage in their language learning inside and outside of classroom. According to Benson (2001), autonomous learners are those who can reflect on their learning at appropriate times and make actions based on the reflection. Self-reflection has started to be used in Japanese contexts more often with the intention of enhancing LA. For example, Noguchi and McCarthy (2010) used two selfreflective modules in which the researchers focused on offering personalized feedback to scaffold reflection skills for the research participants over a given period of time. Such personalized instruction, focusing on exchanges between teachers and students, has generally resulted in improving reflection skills among language learners (Lee, 2016).

Motivation is a concept that has been often tied in with LA. Ryan and Deci (2000) explained the relationship between motivation and LA in the Self-Determination Theory. According to the theory, intrinsic motivation, which is defined as "doing something because it is inherently interesting or enjoyable" (Ryan \& Deci, 2000, p. 55), is fostered in an educational setting which increases the levels of autonomy, relatedness (a feeling of belonging through being valued and cared for by the teacher), and competence. Narrowing down the scope to the role of autonomy in the theory, the researchers further pointed out that students can reinforce their intrinsic motivation when they are given control over their learning process.

Only a few studies have investigated learners' perceptions of LA in the Japanese university EFL context. According to Sakai and Takagi (2009), in their study, the participants $(N=721)$ showed negative views toward taking responsibility for classroom-related decisions regardless of their language proficiency; further, higher proficiency learners tend not to be involved with classroom decision-making processes because they believe in the ability of their teachers to make decisions regarding their courses. Shimo (2008) investigated the correlation between proficiency levels and learners' orientation toward improvement on learning environments and reflective learning and found a positive correlation between reflective learning and proficiency levels. However, no significant difference was found between the orientation toward improvement of learning environment and proficiency. 
The two studies investigated LA perceptions of learners with quantitative approaches. However, qualitative investigation of learners' perceptions is also necessary to learn what lies behind learner perceptions. Therefore, employing both qualitative and quantitative methods, this study set out the following research questions.

1. How do Japanese university EFL learners of different proficiency levels view the responsibilities of learners and teachers in learning English?

2. How do they view their ability to learn English autonomously?

3. What different learning activities and behaviors have they utilized and at what frequency?

\section{Participants}

\section{Methodology}

The participants of this study are 102 EFL learners at a private university in Japan. The participants were selected from a variety of English courses to represent learners of different proficiency levels and language learning experience. The participants were freshmen to senior students, including those who had studied abroad. Based on their TOEIC scores, the participants were categorized into two proficiency levels. The higher proficiency (HP) students $(n=36)$ were those whose TOEIC scores were above 600 , while the lower proficiency (LP) students $(n=66)$ had scores below 285. Sixteen students (5 HP and 11 LP) voluntarily participated in follow-up interviews. The interview participants were selected based on availability and full completion of the questionnaire.

\section{Instruments}

This study employed a questionnaire as a quantitative data collection tool and interviews as a qualitative data collection method to gain in-depth understanding of the questionnaire results.

Questionnaire. The questionnaire was adopted from Chan, Spratt, and Humphreys (2002) and slightly modified to fit the context of the present study (see Appendix A). Likert-type scales were used. The 47 questionnaire items were translated into Japanese by the lead author, and the translation was checked by a Japanese-English bilingual faculty member at the university. The questionnaire was conducted online to investigate (a) learner perspectives regarding the responsibilities of teachers and students on items such as goal setting in class and decision making regarding materials to be used inside and outside class, (b) the students' views on their current ability to learn English autonomously inside and outside class, (c) the degree of their motivation, and (d) the learning activities and behaviors that they have engaged in. Although the questionnaire asked about the participants' levels of motivation, this paper will not discuss the results because the focus of this study is not the investigation of learners' motivation to learn English.

Interviews. Semi-structured interviews were conducted to understand in more detail the learner responses in the questionnaire (see Appendix E). In the interviews, the participants provided further explanation of their questionnaire responses using their language learning experiences and perspectives (see Appendix F). All the interviews were administered in Japanese due to the interviewees' preference, and the responses were audio-recorded.

The interviews were first transcribed in Japanese. The transcribed interviews were then translated into English by a Japanese-English bilingual faculty member at the university. After the translation process, a qualitative approach was used to analyze the interview data. The interview data were categorized into the themes investigated in the questionnaire. These classified learner responses were used to support the questionnaire results in more depth and as 
a basis for the possible learner autonomy-enhancing classroom activities described in the educational implications section.

\section{Results and Discussion Responsibilities of Learners and Teachers in Learning English}

The first section of the questionnaire examined the learners' perspectives on the responsibilities of learners themselves and their teachers inside and outside the classroom. Table B (see Appendix B) presents learners' views on how much responsibility learners and their teachers should have in the actions described in this section. For the smooth interpretation of the data, not and a little were categorized together, as were mainly and completely.

HP learners. HP learners tend to view behaviors shown in Items 1 (make sure of progress in a lesson), 3 (stimulate your interest in learning English), 4 (identify your weakness in your English), 5 (increase your motivation), and 6 (decide the objectives of your English course) as having shared responsibility. Approximately $80 \%$ or more of the HP learners responded that both learners and teachers are mainly responsible for those behaviors. Over $90 \%$ of the participants responded that Items 9 (decide the duration of each classroom activity) and 11 (evaluate your learning) are the areas for which they considered teachers to be mainly or completely responsible. Regarding Items 7 (decide the content of the next English lesson), 8 (choose activities for the next lesson), and 10 (choose materials to use in your English course), all $36 \mathrm{HP}$ learners answered that teachers were mainly or completely responsible. On the other hand, a higher percentage of HP learners perceived that learners themselves, compared to teachers, are mainly or completely responsible for behaviors in Items 2 (make sure of your progress in your self-study, 94\%) and 13 (decide what to learn in your self-study, 86\%). These questionnaire results are supported by the interview data, which indicates HP learners prefer their teachers to make decisions that affect the entire class.

LP learners. Overall, the LP students expect teachers to take a great extent of the responsibility toward their learning; however, they expressed high learner responsibility toward selfevaluation in Items 1 (79\%) and 4 (89\%) and self-guided learning in Items 3 (68\%) and 13 $(67 \%)$. On the other hand, much lower percentages of LP students showed they should be responsible for selecting content of lessons as shown in Item 7 (33\%) and materials of the course as indicated in Item 10 (27\%).

The semi-structured interviews revealed a variety of views on selecting content and materials for courses. Ten of the LP learners would like to be involved in deciding course materials and lesson content, but they do not know how to choose these because they have never been involved with such classroom decision making. The majority of the LP students feel that they should also be responsible for the evaluation of the course with their teachers. Some LP students answered that they were familiar with evaluating their courses in general because they have to fill in course evaluation questionnaires at the end of each semester.

\section{The Ability to Learn English Autonomously}

Table C (Appendix C) indicates how learners view their ability to be autonomous in their learning process. Learners rated their abilities on a 5-point Likert-type scale, with 1 meaning Very poor, 3 meaning $O K$, and 5 meaning Very good. The choice $O K$ was included for learners who feel their ability to be autonomous is neither poor nor good. The responses Very poor and poor were categorized together, and good and very good were also classified into one category for the ease of interpretation. 
HP learners. HP learners' views on their own ability to make decisions differ depending on whether their decision is about their self-study or their English classes. These learners tend to show confidence in their decision-making abilities to choose learning activities outside class (Item 15, 78\%) and learning objectives for their self-study (Item 17, 78\%). However, approximately $80 \%$ expressed that their ability to choose the content (Item 18) and learning materials (Item 20) for their class was poor or very poor.

Lack of confidence in decision making is possibly a major cause of this seemingly dependent view regarding class-related decision making. Four of the HP interview participants answered that they were not sure what variety of activities, materials, and strategies were available for what purposes. According to them, this limited knowledge causes them to be unsure whether other classmates can benefit from their decisions. The HP learners expressed that their lack of confidence in decision making leads them to view that teachers should take responsibility for class-related decisions.

LP learners. For LP learners, the results elicited in this section have similar tendencies regarding decision making to those that were found in the previous section. The LP group perceived that they had good or very good abilities regarding self-study and course evaluation shown in Items $15(53 \%), 17(48 \%), 19(47 \%)$, and $23(45 \%)$. At the same time, less than $25 \%$ of the LP students reported that they would be very poor or poor in conducting actions described. In the interviews, LP learners reported that the materials they selected tended not to match their goals. For example, some interview participants stated that they wanted to increase their fluency but were studying only reading and listening for the TOEIC test.

Responses in Item 18 (68\%) and Item 20 (64\%) indicated that LP learners have less confidence in their ability to select lesson content and materials. The interview data suggested that they did not believe that they were capable of choosing appropriate content or materials that would meet the demands of the greatest number of students.

\section{Learning Activities and Behaviors}

Table D (see Appendix D) shows the percentages of HP learners who engaged in the learning activities and behaviors outside of class specified in Items 26 to 42 and the learning behaviors in class in Items 43-47. Learner responses never and rarely were grouped into one category, and sometimes and often were categorized into another category for ease of interpretation.

\section{Learning activities and behaviors outside of the class.}

HP learners. In general, HP learners employed a wide range of activities for improving their English, but the frequencies of the use of the activities differed widely. For example, over $80 \%$ of the HP learners reported that they listened to English songs (83\%, Item 34), talked to foreigners in English (81\%, Item 35) and used the internet (97\%, Item 40). On the other hand, only a small body of the HP learners have sometimes or often engaged in certain activities such as writing a diary in English (11\%, Item 39$)$ and doing grammar exercises (28\%, Item 37$)$. In the interviews, HP learners also expressed a willingness to learn about more learning activities. They added that knowing which activities were beneficial and effective for improving particular skills was helpful for them.

$L P$ learners. The majority of the LP group chose never or rarely for all but two of the items in this section regarding the frequency of using learning activities for their self-study. In particular, more than $90 \%$ of the LP learners reported that they never or rarely read newspapers $(95 \%$, Item 29), do self-study in a group (91\%, Item 36), or keep an English diary (97\%, Item 39). Among the items in the practiced outside the classroom, the respondents reported they 
sometimes or often use English songs (76\%, Item 34$)$ and movies (50\%, Item 38) as learning activities outside of the classroom.

The interview results indicate that the LP group selects fewer learning activities for their selfguided learning. Five interviewees attribute this tendency to their lack of experience in using activities and in receiving training from the teacher. One interview participant answered that he was not taught about learning activities by his teacher nor was he familiar with the activities.

\section{Learning behaviors inside class.}

HP learners. The majority of HP learners have sometimes or often engaged in various autonomous behaviors in class, except for making suggestions to teachers. In the interviews, $\mathrm{HP}$ learners expressed their willingness to be more involved in class-related decisions. However, voicing opinions that can affect the entire class seemed to be their challenge. Only $11 \%$ of the HP learners sometimes or often made suggestions to their teachers (Item 45). Considering the questionnaire results and those of the interviews, the primary obstacle lying behind such challenges seems to be the learners' confidence issues regarding class-related decisions.

LP learners. Similar to HP learners, making suggestions to their teachers (Item 45) was the least frequent behavior by LP learners. Only $9 \%$ of them answered they have often or sometimes made suggestions to their teachers.

Considering the top-down model of education in Japan (Nakata, 2011), the participants' overall answers fairly articulate the continued effects of classrooms of such nature on their behaviors in the classroom. In particular, the majority of participants answered that they never or rarely give suggestions to their teachers. Giving suggestions to a higher status figure constitutes a highly face-threatening act, so students in countries with Confucian ethics, including Japan, tend to avoid letting such situations happen (Doi, 1994; Wang, Pomerantz \& Chen, 2007).

\section{Educational Implications}

\section{Higher Proficiency Group}

Based on the questionnaire and interview results, this section offers some ideas of what teachers can do to enhance their HP students' learner autonomy levels. The first idea is to clarify the pedagogical outcomes of assignments and learning activities. This can serve multiple purposes in terms of enhancing their students' autonomy levels. For example, this can be a way for teachers to fuel learners' motivation to study English. All of the HP interviewees mentioned that they would be motivated if they could clearly see what skills could be improved by specific activities. In addition, a clear explanation of pedagogical goals can enable learners to be confidently involved in class-related decision making processes. HP learners expressed their willingness to be involved in decision making so that they can create a class that is more in line with learner needs. However, their involvement is hampered by their lack of confidence in making class-related decisions such as choosing class activities. HP learners expressed concern that their choices may not be beneficial for other students, and therefore, teachers should decide on the class activities, materials, and contents. Knowing the pedagogical outcomes of class activities and assignments may alleviate this anxiety and eventually provide HP learners confidence in making class-related decisions.

Encouraging learner choices in class through scaffolding decision making is another action that teachers can implement. The study results indicate that HP learners tend to place the responsibility to make class-related decisions on teachers despite the learners' willingness to 
increase their involvement in decision making in class. To fill this gap, decision making should be scaffolded for learners. Teachers can start with involving learners in relatively easy decision making, such as providing choices regarding the sequence of activities (Nunan, 2003). Through decision-making, the involvement of learners in their English classes can be enhanced (Benson, 2001).

Giving HP learners opportunities to reflect on their own progress and evaluate their learning process is an action teachers can do to enhance learner autonomy. In the questionnaire, over $80 \%$ of HP learners responded that learners as well as teachers are responsible for making sure of learners' progress in the classroom, and identifying their weakness. Although actualizing the complete shift of such responsibility from teachers to learners may be challenging, as a suggestion, learning diaries and evaluation sheets can provide learners with opportunities to gauge their own learning (Sakai, Takagi, \& Chu, 2010). In the use of those tools, it may be teachers who create the criteria of what to reflect on in most cases. However, students can learn what aspects of learning they should pay attention to when reflecting on their learning process. If HP learners can increase their confidence in evaluating their own progress, this can lead to increased confidence and ability to decide class objectives.

\section{Lower Proficiency Group}

LP learners should be provided with more decision-making opportunities. According to the questionnaire and interview results, LP learners feel they should be less responsible or are less competent to be involved in class-related decision making. This attitude derives from their lack of such decision-making experience. Students need teachers to train and support them by providing them with opportunities to participate in selecting course materials, content, or evaluation methods to be more autonomous learners (Nunan, 2003). Such in-class support will not only increase students' contribution to classroom decision making process but also foster skills to select appropriate materials for their own learning (Noguchi \& McCarthy, 2010).

Improvements in the ability to choose appropriate learning materials can encourage LP learners to study English independently in an effective manner. In this study, discrepancies between learners' goals and means were found. If LP learners can employ means that can directly address their goals, they are more likely to improve their target skills. To help LP learners with their skills, teachers can suggest some online materials. Online materials such as podcasts, short YouTube video clips, and other learning websites are easy to access and provide learning materials of a wide range of levels.

Lastly, giving LP learners chances to measure their own progress can be effective in enhancing LA. For example, taking a test could provide learners with immediate feedback on their language learning progress. By taking a test, they can see where they stand in their language learning. If they see any progress, that may give them confidence that their study methods are effective. If they cannot see progress, they should be encouraged to reflect on their learning methods (Benson, 2001).

\section{Research Limitations}

This study did not examine the impact of variables such as majors, year of study, and learning experience of the research participants, which might have had some influence on the questionnaire results. Given the shortcomings of the current research, future research can examine how these variables influence the development of learner autonomy and provide some direction to create approaches to elevate the autonomy levels of learners with different needs. 


\section{Conclusion}

This study investigated the perceptions of Japanese university EFL learners of different proficiency levels on the responsibilities of learners and teachers, their ability to carry out autonomous actions, and the frequency that they employed a variety of learning activities and behaviors. The major need of the HP learners in this study is to receive clear explanations on pedagogical purposes for inside and outside classroom activities. This will enable HP learners to engage in self-guided learning in a more efficient manner. The needs found in the study for the LP group are the involvement to decision making regarding language learning in and outside of the class, constant assessment of their own learning process, and the use of a wider variety of learning activities and behaviors. Aside from the challenges found in the study for both groups, such as their lower confidence in making classroom-related decisions, the study highlights that both HP and LP learners possess willingness to be involved in decision making inside and outside class, especially in the selection of course content and materials. With such willingness, familiarizing learners with a wider variety of learning materials, activities, and behaviors is what teachers can do in class. By understanding learner needs and appropriately scaffolding decision making, teachers can guide and support their learners in developing learner autonomy regardless of their current proficiency levels.

\section{Author Note}

Koki Tomita, World Language Center, Soka University, Tokyo, Japan; Maho Sano, World Language Center, Soka University, Tokyo, Japan.

Koki Tomita is a lecturer at Soka University Japan. He has taught lower level English courses, and this teaching experience interests him to find how to improve the autonomy of lower level students. His current research interest is practical applications of learner autonomy and learner motivation.

Maho Sano is an Assistant Lecturer at Soka University. She has taught four-skills courses and test preparation courses, in particular, beginner level classes. She has also coordinated a semester-long independent learning program on campus. Her primary academic interests are learner autonomy and critical thinking in language education.

Correspondence concerning this article should be addressed to Koki Tomita or Maho Sano, World Language Center, Soka University, 1-236 Tangi-machi, Hachioji-shi, Tokyo 192-8577, Japan. E-mail: tomita.koki@gmail.com,maho.tesol@gmail.com 


\section{References}

Ahmadi, R., \& Mahdavi-Zafarghandi, A. (2013). Autonomous language learning in Iranian context: To what extent do students take responsibility for their learning? International Journal of Research Studies in Language Learning, 2(5), 17-26.

https://doi.org/10.5861/ijrsll.2013.242

Benson, P. (2001). Teaching and researching autonomy (2nd ed.). London, England: Pearson Education.

Chan, V., Spratt, M., \& Humphreys, G. (2002). Autonomous language learning: Hong Kong tertiary students' attitudes and behaviors. Research and Evaluation in Education, 16(1), 1-18. https://doi.org/10.1080/09500790208667003

Doi, T. (1994). The anatomy of dependence (J. Bester, Trans.). New York, NY: Kodansha America.

Holec, H. (1981). Autonomy and foreign language learning. Oxford, England: Pergamon.

Lee, L. (2016). Autonomous learning through task-based instruction in fully online language courses. Language Learning \& Technology, 20(2), 81-97. Available at http://lt.msu.edu/issues/june2016/lee.pdf

Littlewood, W. (1999). Defining and developing autonomy in East Asian contexts. Applied Linguistics, 20(1), 71-94. https://doi.org/10.1093/applin/20.1.71

Nakata, Y. (2011). Teachers' readiness for promoting learner autonomy: A study of Japanese EFL high school teachers. Teaching and Teacher Education, 27, 900-910. https://doi.org/10.1016/j.tate.2011.03.001

Noguchi, J., \& McCarthy, T. (2010). Reflective self-study: Fostering learner autonomy. In A. M. Stoke (Ed.), JALT 2009 Conference Proceedings, Japan (pp. 160-167). Retrieved from http://jalt-publications.org/archive/proceedings/2009/E051.pdf

Nunan, D. (2003). Nine steps to learner autonomy. In M. Olofsson (Ed.), Symposium 2003 (pp. 193-204). Retrieved from

http://www.andrasprak.su.se/polopoly_fs/1.84007.1333707257!/menu/standard/file/200 3_11_Nunan_eng.pdf

Ryan, M. R., \& Deci, L. E. (2000). Intrinsic and extrinsic motivations: Classic definitions and new directions. Contemporary Educational Psychology, 25, 54-67. https://doi.org/10.1006/ceps.1999.1020

Sakai, S., \& Takagi, A. (2009). Relationship between learner autonomy and English language proficiency of Japanese learners. The Journal of Asia TEFL, 6(3), 297-325. Retrieved from www.asiatefl.org/main/download_pdf.php?i=220\&c=1419309891

Sakai, S., Takagi, A., \& Chu, M. (2010). Promoting learner autonomy: Student perceptions of responsibilities in a language classroom in East Asia. Educational Perspectives, 43(1 \& 2), 12-27. Retrieved from http://files.eric.ed.gov/fulltext/EJ912111.pdf

Shimo, E. (2008). Learner autonomy and English language proficiency: An exploration among non-English majors at a Japanese university. Kinkidaigaku gogaku kyōiku gakubu kiyō [Kinki University Department of Language Education bulletin], 8(2), 153-178. Retrieved from

https://kindai.repo.nii.ac.jp/?action=repository_uri\&item_id=13282\&file_id=40\&file_no $=1$

Wang, Q., Pomerantz, E. M., \& Chen, H. (2007). The role of parents' control in early adolescents' psychological functioning: A longitudinal investigation in the United States and China. Child Development, 78(5), 1592-1610. https://doi.org/10.1111/j.14678624.2007.01085.x

Wenden, L. A. (1998). Metacognitive knowledge and language learning. Applied Linguistics, 19(14), 515-537. https://doi.org/10.1093/applin/19.4.515 


\section{Appendix A \\ Learner Autonomy Questionnaire \\ (Adapted from Chan, Spratt, \& Humphreys, 2002)}

Grade

TOEIC Score

Section 1: Responsibilities (Please check $\boldsymbol{V}$ both "Yours" and "Your teacher's" choices)

When you are taking English classes, whose responsibility should it be to:

\begin{tabular}{|c|c|c|c|c|c|c|}
\hline & & & Not at all & A little & Mainly & Completely \\
\hline \multirow[t]{2}{*}{1.} & \multirow{2}{*}{$\begin{array}{l}\text { make sure of your progress in a } \\
\text { lesson? }\end{array}$} & A. Yours & & & & \\
\hline & & B. Your teacher's & & & & \\
\hline \multirow[t]{2}{*}{2.} & \multirow{2}{*}{$\begin{array}{l}\text { make sure of your progress in your } \\
\text { self-study? }\end{array}$} & A. Yours & & & & \\
\hline & & B. Your teacher's & & & & \\
\hline \multirow[t]{2}{*}{3.} & \multirow{2}{*}{$\begin{array}{l}\text { stimulate your interest in learning } \\
\text { English? }\end{array}$} & A. Yours & & & & \\
\hline & & B. Your teacher's & & & & \\
\hline \multirow[t]{2}{*}{4.} & \multirow[t]{2}{*}{ identify your weakness in your English? } & A. Yours & & & & \\
\hline & & B. Your teacher's & & & & \\
\hline \multirow[t]{2}{*}{5.} & \multirow[t]{2}{*}{ increase your motivation? } & A. Yours & & & & \\
\hline & & B. Your teacher's & & & & \\
\hline \multirow[t]{2}{*}{6.} & \multirow{2}{*}{$\begin{array}{l}\text { decide the objectives of your English } \\
\text { course? }\end{array}$} & A. Yours & & & & \\
\hline & & B. Your teacher's & & & & \\
\hline \multirow[t]{2}{*}{7.} & \multirow{2}{*}{$\begin{array}{l}\text { decide the content of the next English } \\
\text { lesson? }\end{array}$} & A. Yours & & & & \\
\hline & & B. Your teacher's & & & & \\
\hline \multirow[t]{2}{*}{8.} & \multirow[t]{2}{*}{ choose activities for the next lesson? } & A. Yours & & & & \\
\hline & & B. Your teacher's & & & & \\
\hline \multirow[t]{2}{*}{9.} & \multirow{2}{*}{$\begin{array}{l}\text { decide the duration of each classroom } \\
\text { activity? }\end{array}$} & A. Yours & & & & \\
\hline & & B. Your teacher's & & & & \\
\hline \multirow[t]{2}{*}{10.} & \multirow{2}{*}{$\begin{array}{l}\text { choose materials to be used in your } \\
\text { English course? }\end{array}$} & A. Yours & & & & \\
\hline & & B. Your teacher's & & & & \\
\hline \multirow[t]{2}{*}{11.} & \multirow[t]{2}{*}{ evaluate your learning? } & A. Yours & & & & \\
\hline & & B. Your teacher's & & & & \\
\hline \multirow[t]{2}{*}{12.} & \multirow[t]{2}{*}{ evaluate your course? } & A. Yours & & & & \\
\hline & & B. Your teacher's & & & & \\
\hline \multirow[t]{2}{*}{13.} & \multirow[t]{2}{*}{ decide what to learn in your self-study? } & A. Yours & & & & \\
\hline & & B. Your teacher's & & & & \\
\hline
\end{tabular}


Section 2: Abilities (Please check $\boldsymbol{V}$ the choices that describe you the most.)

If you have the following opportunities, how good do you think you would be at:

\begin{tabular}{|c|c|c|c|c|c|}
\hline & $\begin{array}{l}\text { Very } \\
\text { poor }\end{array}$ & Poor & OK & Good & $\begin{array}{l}\text { Very } \\
\text { good }\end{array}$ \\
\hline 14. choosing learning activities for your class? & & & & & \\
\hline 15. choosing learning activities outside class? & & & & & \\
\hline 16. choosing learning objectives for your class? & & & & & \\
\hline 17. choosing learning objectives for your self-study? & & & & & \\
\hline 18. choosing the content of every class? & & & & & \\
\hline 19. evaluating your course? & & & & & \\
\hline 20. choosing learning materials for your class? & & & & & \\
\hline 21. identifying weakness in your English? & & & & & \\
\hline 22. evaluating your learning? & & & & & \\
\hline 23. choosing learning materials to be used outside class? & & & & & \\
\hline 24. deciding the duration of each activity in your self-study? & & & & & \\
\hline
\end{tabular}

Section 3: Motivation (Please choose the best answer that describes you the most.)

\begin{tabular}{|l|l|l|l|l|l|}
\hline & Very high How low \\
\hline 25. How high is your motivation to learn English? & & & & & \\
\hline
\end{tabular}

Section 4: Activities and Behaviors (Please check $\boldsymbol{V}$ the answer that describes you the most.)

In this academic year, how often have you:

\section{Outside Class}

\begin{tabular}{|l|l|l|l|l|}
\hline 26. $\quad$ read grammar books on your own? & & & & \\
\hline 27. done assignments which are not compulsory? & & & & \\
\hline 28. noted down new words and their meanings? & & & & \\
\hline 29. read newspaper in English? & & & & \\
\hline 30. sent emails in English? & & & & \\
\hline 31. read books or magazines in the English? & & & \\
\hline 32. watched English TV programs? & & & \\
\hline 33. listened to the radio or podcast in English? & & & \\
\hline 34. listened to English songs? & & & & \\
\hline 35. talked with foreigners in English? & & & & \\
\hline 36. done English self-study in a group? & & & & \\
\hline 37. done grammar exercises? & & & \\
\hline 38. watched English movies? & & & \\
\hline 39. written a diary in English? & & & \\
\hline $40 . \quad$ used the internet in English? & & & \\
\hline $41 . \quad$ revised your written work without being told to do so? & & & \\
\hline 42. attended a self-study center, for example a CALL room? & & & \\
\hline
\end{tabular}




\section{Inside Class}

\begin{tabular}{|ll|l|l|l|l|}
\hline 43. $\quad$ asked the teacher questions when you didn't understand? & & & & \\
\hline $44 . \quad$ noted down new information? & & & & \\
\hline $45 . \quad$ made suggestions to the teacher? & & & & \\
\hline $46 . \quad$ taken opportunities to speak in English? & & & & \\
\hline $47 . \quad$ discussed problems in learning with your classmates? & & & & \\
\hline
\end{tabular}




\section{Appendix B \\ Results for Section 1 of the Learner Autonomy Questionnaire}

Table B

Participants' Perceptions of Their and Their Teachers' Responsibilities

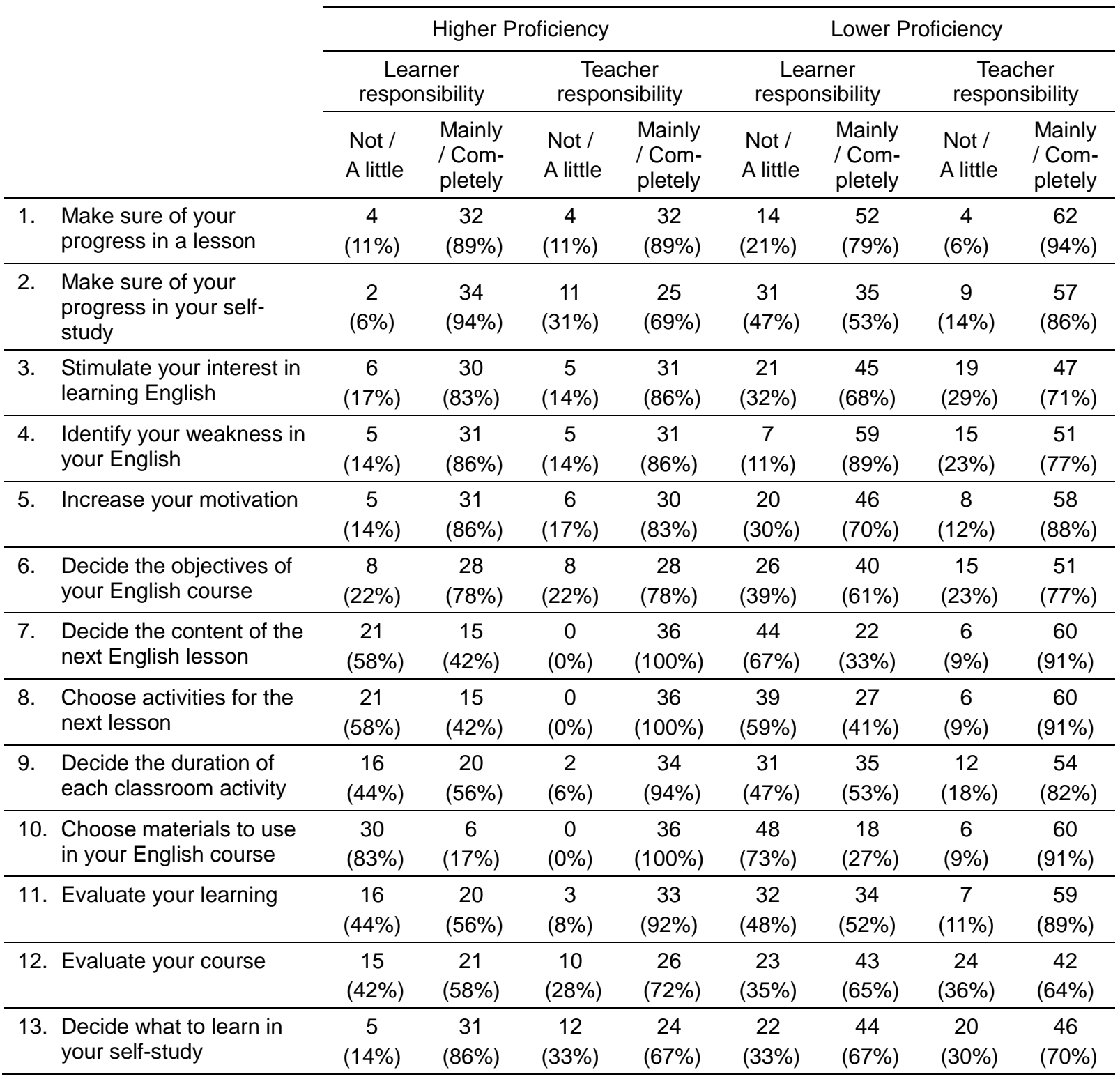




\section{Appendix C \\ Results for Section 2 of the Learner Autonomy Questionnaire}

Table C

Participants' Views of Their Abilities in Taking Responsibility In and Outside Class

\begin{tabular}{|c|c|c|c|c|c|c|}
\hline & \multirow{2}{*}{\multicolumn{3}{|c|}{ Higher Proficiency }} & \multirow{2}{*}{\multicolumn{3}{|c|}{ Lower Proficiency }} \\
\hline & & & & & & \\
\hline & $\begin{array}{l}\text { Very poor } \\
\text { / Poor }\end{array}$ & OK & $\begin{array}{l}\text { Good / } \\
\text { Very good }\end{array}$ & $\begin{array}{l}\text { Very poor } \\
\text { / Poor }\end{array}$ & OK & $\begin{array}{l}\text { Good / } \\
\text { Very good }\end{array}$ \\
\hline $\begin{array}{l}\text { 14. Choosing learning activities } \\
\text { for your class }\end{array}$ & $\begin{array}{c}14 \\
(39 \%)\end{array}$ & $\begin{array}{c}15 \\
(42 \%) \\
\end{array}$ & $\begin{array}{c}7 \\
(19 \%) \\
\end{array}$ & $\begin{array}{c}21 \\
(32 \%) \\
\end{array}$ & $\begin{array}{c}26 \\
(39 \%) \\
\end{array}$ & $\begin{array}{c}19 \\
(29 \%) \\
\end{array}$ \\
\hline $\begin{array}{l}\text { 15. Choosing learning activities } \\
\text { outside class }\end{array}$ & $\begin{array}{c}5 \\
(14 \%) \\
\end{array}$ & $\begin{array}{c}3 \\
(8 \%) \\
\end{array}$ & $\begin{array}{c}28 \\
(78 \%) \\
\end{array}$ & $\begin{array}{c}6 \\
(9 \%) \\
\end{array}$ & $\begin{array}{c}25 \\
(38 \%) \\
\end{array}$ & $\begin{array}{c}35 \\
(53 \%) \\
\end{array}$ \\
\hline $\begin{array}{l}\text { 16. Choosing learning } \\
\text { objectives for your class }\end{array}$ & $\begin{array}{c}5 \\
(14 \%) \\
\end{array}$ & $\begin{array}{c}15 \\
(42 \%) \\
\end{array}$ & $\begin{array}{c}16 \\
(44 \%) \\
\end{array}$ & $\begin{array}{c}21 \\
(32 \%) \\
\end{array}$ & $\begin{array}{c}24 \\
(36 \%) \\
\end{array}$ & $\begin{array}{c}21 \\
(32 \%) \\
\end{array}$ \\
\hline $\begin{array}{l}\text { 17. Choosing learning } \\
\text { objectives for your self-study }\end{array}$ & $\begin{array}{c}4 \\
(11 \%) \\
\end{array}$ & $\begin{array}{c}4 \\
(11 \%) \\
\end{array}$ & $\begin{array}{c}28 \\
(78 \%) \\
\end{array}$ & $\begin{array}{c}15 \\
(23 \%) \\
\end{array}$ & $\begin{array}{c}19 \\
(29 \%) \\
\end{array}$ & $\begin{array}{c}32 \\
(48 \%) \\
\end{array}$ \\
\hline $\begin{array}{l}\text { 18. Choosing the content of } \\
\text { every class }\end{array}$ & $\begin{array}{c}29 \\
(81 \%) \\
\end{array}$ & $\begin{array}{c}6 \\
(17 \%) \\
\end{array}$ & $\begin{array}{c}1 \\
(3 \%)\end{array}$ & $\begin{array}{c}45 \\
(68 \%)\end{array}$ & $\begin{array}{c}12 \\
(18 \%)\end{array}$ & $\begin{array}{c}9 \\
(14 \%)\end{array}$ \\
\hline 19. Evaluating your course & $\begin{array}{c}2 \\
(6 \%) \\
\end{array}$ & $\begin{array}{c}17 \\
(47 \%) \\
\end{array}$ & $\begin{array}{c}17 \\
(47 \%) \\
\end{array}$ & $\begin{array}{c}13 \\
(20 \%) \\
\end{array}$ & $\begin{array}{c}22 \\
(33 \%) \\
\end{array}$ & $\begin{array}{c}31 \\
(47 \%) \\
\end{array}$ \\
\hline $\begin{array}{l}\text { 20. Choosing learning materials } \\
\text { for your class }\end{array}$ & $\begin{array}{c}28 \\
(78 \%) \\
\end{array}$ & $\begin{array}{c}5 \\
(14 \%) \\
\end{array}$ & $\begin{array}{c}3 \\
(8 \%) \\
\end{array}$ & $\begin{array}{c}42 \\
(64 \%) \\
\end{array}$ & $\begin{array}{c}14 \\
(21 \%) \\
\end{array}$ & $\begin{array}{c}10 \\
(15 \%) \\
\end{array}$ \\
\hline $\begin{array}{l}\text { 21. Identifying your weaknesses } \\
\text { in English }\end{array}$ & $\begin{array}{c}4 \\
(11 \%) \\
\end{array}$ & $\begin{array}{c}14 \\
(39 \%) \\
\end{array}$ & $\begin{array}{c}18 \\
(50 \%) \\
\end{array}$ & $\begin{array}{c}16 \\
(24 \%) \\
\end{array}$ & $\begin{array}{c}23 \\
(35 \%)\end{array}$ & $\begin{array}{c}27 \\
(41 \%)\end{array}$ \\
\hline 22. Evaluating your learning & $\begin{array}{c}7 \\
(19 \%) \\
\end{array}$ & $\begin{array}{c}16 \\
(44 \%) \\
\end{array}$ & $\begin{array}{c}13 \\
(36 \%) \\
\end{array}$ & $\begin{array}{c}22 \\
(33 \%) \\
\end{array}$ & $\begin{array}{c}24 \\
(36 \%) \\
\end{array}$ & $\begin{array}{c}20 \\
(30 \%) \\
\end{array}$ \\
\hline $\begin{array}{l}\text { 23. Choosing learning materials } \\
\text { to be used outside class }\end{array}$ & $\begin{array}{c}7 \\
(19 \%) \\
\end{array}$ & $\begin{array}{c}14 \\
(39 \%) \\
\end{array}$ & $\begin{array}{c}15 \\
(42 \%) \\
\end{array}$ & $\begin{array}{c}15 \\
(23 \%) \\
\end{array}$ & $\begin{array}{c}21 \\
(32 \%)\end{array}$ & $\begin{array}{c}30 \\
(45 \%)\end{array}$ \\
\hline $\begin{array}{l}\text { 24. Determining of the duration } \\
\text { of each activity in your self- } \\
\text { study }\end{array}$ & $\begin{array}{c}5 \\
(14 \%)\end{array}$ & $\begin{array}{c}8 \\
(22 \%)\end{array}$ & $\begin{array}{c}23 \\
(64 \%)\end{array}$ & $\begin{array}{c}17 \\
(26 \%)\end{array}$ & $\begin{array}{c}20 \\
(30 \%)\end{array}$ & $\begin{array}{c}29 \\
(44 \%)\end{array}$ \\
\hline
\end{tabular}




\section{Appendix D}

\section{Results for Section 4 of the Learner Autonomy Questionnaire}

\section{Table D}

\section{Frequency of Using Learning Activities and Behaviors In and Outside Class}

\begin{tabular}{|c|c|c|c|c|}
\hline & \multicolumn{2}{|c|}{ Higher Proficiency } & \multicolumn{2}{|c|}{ Lower Proficiency } \\
\hline & $\begin{array}{l}\text { Never / } \\
\text { Rarely }\end{array}$ & $\begin{array}{l}\text { Sometimes / } \\
\text { Often }\end{array}$ & $\begin{array}{l}\text { Never / } \\
\text { Rarely }\end{array}$ & $\begin{array}{c}\text { Sometimes / } \\
\text { Often }\end{array}$ \\
\hline 26. Read grammar books on your own & $\begin{array}{c}24 \\
(67 \%)\end{array}$ & $\begin{array}{c}12 \\
(33 \%)\end{array}$ & $\begin{array}{c}52 \\
(79 \%)\end{array}$ & $\begin{array}{c}14 \\
(21 \%)\end{array}$ \\
\hline 27. Do assignments which are not compulsory & $\begin{array}{c}15 \\
(42 \%)\end{array}$ & $\begin{array}{c}21 \\
(58 \%)\end{array}$ & $\begin{array}{c}42 \\
(64 \%)\end{array}$ & $\begin{array}{c}24 \\
(36 \%)\end{array}$ \\
\hline 28. Note down new words and their meanings & $\begin{array}{c}14 \\
(39 \%)\end{array}$ & $\begin{array}{c}22 \\
(61 \%)\end{array}$ & $\begin{array}{c}38 \\
(58 \%)\end{array}$ & $\begin{array}{c}28 \\
(42 \%)\end{array}$ \\
\hline 29. Read newspaper in English & $\begin{array}{c}20 \\
(56 \%)\end{array}$ & $\begin{array}{c}16 \\
(44 \%)\end{array}$ & $\begin{array}{c}63 \\
(95 \%)\end{array}$ & $\begin{array}{c}3 \\
(5 \%)\end{array}$ \\
\hline 30. Send emails in English & $\begin{array}{c}10 \\
(28 \%)\end{array}$ & $\begin{array}{c}26 \\
(72 \%)\end{array}$ & $\begin{array}{c}55 \\
(83 \%)\end{array}$ & $\begin{array}{c}11 \\
(17 \%)\end{array}$ \\
\hline 31. Read books or magazines in English & $\begin{array}{c}13 \\
(36 \%)\end{array}$ & $\begin{array}{c}23 \\
(64 \%)\end{array}$ & $\begin{array}{c}58 \\
(88 \%)\end{array}$ & $\begin{array}{c}8 \\
(12 \%)\end{array}$ \\
\hline 32. Watch English TV programs & $\begin{array}{c}17 \\
(47 \%)\end{array}$ & $\begin{array}{c}19 \\
(53 \%)\end{array}$ & $\begin{array}{c}55 \\
(83 \%) \\
\end{array}$ & $\begin{array}{c}11 \\
(17 \%)\end{array}$ \\
\hline 33. Listen to radio or podcasts in English & $\begin{array}{c}19 \\
(53 \%)\end{array}$ & $\begin{array}{c}17 \\
(47 \%)\end{array}$ & $\begin{array}{c}57 \\
(86 \%)\end{array}$ & $\begin{array}{c}9 \\
(14 \%)\end{array}$ \\
\hline 34. Listen to English songs & $\begin{array}{c}6 \\
(17 \%)\end{array}$ & $\begin{array}{c}30 \\
(83 \%)\end{array}$ & $\begin{array}{c}16 \\
(24 \%)\end{array}$ & $\begin{array}{c}50 \\
(76 \%)\end{array}$ \\
\hline 35. Talk with foreigners in English & $\begin{array}{c}7 \\
(19 \%) \\
\end{array}$ & $\begin{array}{c}29 \\
(81 \%) \\
\end{array}$ & $\begin{array}{c}53 \\
(80 \%) \\
\end{array}$ & $\begin{array}{c}13 \\
(20 \%) \\
\end{array}$ \\
\hline 36. Do English self-study in a group & $\begin{array}{c}23 \\
(64 \%) \\
\end{array}$ & $\begin{array}{c}13 \\
(36 \%) \\
\end{array}$ & $\begin{array}{c}60 \\
(91 \%) \\
\end{array}$ & $\begin{array}{c}6 \\
(9 \%) \\
\end{array}$ \\
\hline 37. Do grammar exercises & $\begin{array}{c}26 \\
(72 \%) \\
\end{array}$ & $\begin{array}{c}10 \\
(28 \%) \\
\end{array}$ & $\begin{array}{c}42 \\
(64 \%) \\
\end{array}$ & $\begin{array}{c}24 \\
(36 \%) \\
\end{array}$ \\
\hline 38. Watch English movies & $\begin{array}{c}13 \\
(36 \%)\end{array}$ & $\begin{array}{c}23 \\
(64 \%) \\
\end{array}$ & $\begin{array}{c}33 \\
(50 \%) \\
\end{array}$ & $\begin{array}{c}33 \\
(50 \%) \\
\end{array}$ \\
\hline 39. Write a diary in English & $\begin{array}{c}32 \\
(89 \%) \\
\end{array}$ & $\begin{array}{c}4 \\
(11 \%) \\
\end{array}$ & $\begin{array}{c}64 \\
(97 \%) \\
\end{array}$ & $\begin{array}{c}2 \\
(3 \%) \\
\end{array}$ \\
\hline 40. Use the internet in English & $\begin{array}{c}1 \\
(3 \%) \\
\end{array}$ & $\begin{array}{c}35 \\
(97 \%) \\
\end{array}$ & $\begin{array}{c}51 \\
(77 \%) \\
\end{array}$ & $\begin{array}{c}15 \\
(23 \%) \\
\end{array}$ \\
\hline $\begin{array}{l}\text { 41. Revise your written work without being told to } \\
\text { do so }\end{array}$ & $\begin{array}{c}12 \\
(33 \%) \\
\end{array}$ & $\begin{array}{c}24 \\
(67 \%) \\
\end{array}$ & $\begin{array}{c}46 \\
(70 \%) \\
\end{array}$ & $\begin{array}{c}20 \\
(30 \%) \\
\end{array}$ \\
\hline $\begin{array}{l}\text { 42. Attend a self-access center, for example, a } \\
\text { CALL room }\end{array}$ & $\begin{array}{c}27 \\
(75 \%) \\
\end{array}$ & $\begin{array}{c}9 \\
(25 \%) \\
\end{array}$ & $\begin{array}{c}58 \\
(88 \%) \\
\end{array}$ & $\begin{array}{c}8 \\
(12 \%) \\
\end{array}$ \\
\hline $\begin{array}{l}\text { 43. Ask the teacher questions when you didn't } \\
\text { understand }\end{array}$ & $\begin{array}{c}14 \\
(39 \%) \\
\end{array}$ & $\begin{array}{c}22 \\
(61 \%) \\
\end{array}$ & $\begin{array}{c}30 \\
(45 \%) \\
\end{array}$ & $\begin{array}{c}36 \\
(55 \%) \\
\end{array}$ \\
\hline 44. Note down new information & $\begin{array}{c}5 \\
(14 \%) \\
\end{array}$ & $\begin{array}{c}31 \\
(86 \%) \\
\end{array}$ & $\begin{array}{c}25 \\
(38 \%) \\
\end{array}$ & $\begin{array}{c}41 \\
(62 \%) \\
\end{array}$ \\
\hline 45. Make suggestions to the teacher & $\begin{array}{c}32 \\
(89 \%) \\
\end{array}$ & $\begin{array}{c}4 \\
(11 \%) \\
\end{array}$ & $\begin{array}{c}60 \\
(91 \%) \\
\end{array}$ & $\begin{array}{c}6 \\
(9 \%) \\
\end{array}$ \\
\hline 46. Take opportunities to speak in English & $\begin{array}{c}5 \\
(14 \%) \\
\end{array}$ & $\begin{array}{c}31 \\
(86 \%) \\
\end{array}$ & $\begin{array}{c}38 \\
(58 \%)\end{array}$ & $\begin{array}{c}28 \\
(42 \%)\end{array}$ \\
\hline $\begin{array}{l}\text { 47. Discuss learning problems with your } \\
\text { classmates }\end{array}$ & $\begin{array}{c}17 \\
(47 \%)\end{array}$ & $\begin{array}{c}19 \\
(53 \%)\end{array}$ & $\begin{array}{c}51 \\
(77 \%)\end{array}$ & $\begin{array}{c}15 \\
(23 \%)\end{array}$ \\
\hline
\end{tabular}




\section{Appendix E Sample Interview Questions}

1. What does autonomy mean to you?

2. Do you think it is necessary to improve your autonomy to elevate your English level in general? Why do you think so?

3. Do you think there is any connection between improvement on your English proficiency and autonomy?

4. Comparing with the past, do you think that you have increased your autonomy over the years or after you entered the university up to now?

5. How have you improved your autonomy over the past years or after you entered the university up to now?

6. How often do you reflect on your English language learning or the learning process?

7. What is your reaction if your teacher gives you some room to decide classroom content and grading criteria?

8. Why did you put more weight on teachers' role on Item $X$ in the first section of the questionnaire? What would your answer toward this question have been when you were a first-year student? How has your answer changed?

9. Based on your experience, what do you think are the differences between English education up until high school and university?

10. Have your English teachers in university given you opportunities to improve your learner autonomy?

11. How do you monitor your language learning, how do you check your improvement on your language learning, and how often do you reflect on your study plan and goals?

12. You said you are "confident enough" to Item $X$ in Section 2 of the questionnaire. Why do you think so? Have you ever received any training for that?

13. Would you like to add anything to what you have said? 


\section{Appendix $\mathbf{F}$ \\ Some Interview Excerpts}

HP Learners

1. I want my teachers to provide more practices for self-study to study independently.

2. I would like to know what to do to achieve my goal.

3. I am not sure whether my way of studying can be beneficial for other students.

4. I want to see clear purposes of each activity. That makes me motivated.

5. I would like to be involved in classroom decision making if classes will be held in a way our needs are met.

LP Learners

1. I wish I could be involved in decision making process in my course. But I think teacher should decide the content of the course because he/she is an expert.

2. I need to have some framework to study within. Being given too much freedom is challenging for me.

3. I know how to make small goals but don't know how to set clear goals to achieve my big goal. 